\title{
Parasitoids of the lime leaf miner Phyllonorycter issikii (Lepidoptera: Gracillariidae) recorded throughout the area it recently colonized
}

\author{
LeVENTE SZÖCS ${ }^{1}$, MeLIKa GEORGE², Csaba THURÓCZY³ and György CSÓKA ${ }^{1}$ \\ ${ }^{1}$ NARIC Forest Research Institute, Department of Forest Protection, H-3232 Mátrafüred, Hungary; e-mails: szocsl@erti.hu; \\ csokagy@erti.hu \\ ${ }^{2}$ National Food Chain Safety Office, Directorate of Plant Protection, Soil Conservation and Agri-environment, Plant Health and \\ Molecular Biology Laboratory, H-1118 Budapest, Budaörsi str. 141-14, Hungary; e-mail: melikag@nebih.gov.hu \\ ${ }^{3}$ Malomárok str. 27, H-9730 Kőszeg, Hungary; e-mail: thuroczy.cs@freemail.com
}

Key words. Lepidoptera, Gracillariidae, Phyllonorycter issikii, Tilia cordata, parasitoid assemblages, invasive species

\begin{abstract}
Phyllonorycter issikii (Lepidoptera: Gracillariidae) has recently spread over a considerable part of the Eurasian continent. So far, in Europe, unlike in Russia, it has not significantly affected its food plant (Tilia cordata), but its effect may increase over time. The regulating potential of associated parasitoid natural enemies is still low, which probably allows further leaf miner range expansion and population growth. This species is potentially capable of inflicting considerable damage on its host. Therefore, it is important to study its natural enemies, especially their oviposition behaviour and biology. In this paper, we summarize the results of rearing experiments throughout the area it has recently occupied, including our own study in Hungary. Here we list 46 species of parasitoids recorded from $P$. issikii. None of these species are likely to be able regulate the abundance of $P$. issikii. Further studies are needed to determine their effect on the abundance of this host.
\end{abstract}

\section{INTRODUCTION}

The establishment and later range expansion of a species is largely dependent on the regulating efficiency of native enemies in newly colonized areas (Šefrová, 2003; Ermolaev, 2014). A novel host is a new food resource for the local native parasitoids and predators. Predatory species, like oligophagus Hemiptera (Askew \& Shaw, 1974; Ermolaev et al., 2011) and parasitoid species start to use the novel species as food. As the native natural enemies begin to shift to the novel host, the local food-web becomes more and more complex (Cornell \& Hawkins, 1993, Stone et al., 1995; Schönrogge et al., 1996). The most important mortality factor of leaf miners are hymenopteran parasitoids (Askew \& Shaw, 1974, 1979a; Godfray, 1994; Hawkins, 2005). The threshold percentage parasitism for parasitoid regulation of native leaf miner populations is estimated to be 50\% (Askew \& Shaw, 1979a; Mey, 1991; Szőcs et al., 2013). In contrast, a generally low (less than 25\%) effect of native parasitoid assemblages is recorded for invasive leaf miner species such as Cameraria ohridella (Deschka et Dimič, 1986) (Freise et al., 2002; Grabenweger et al., 2005; Volter \& Kenis, 2006; Matošević \& Melika, 2012), Macrosaccus robiniella (Clemens, 1959) and Parectopa robiniella (Clemens, 1863) (Csóka et al., 2009) and Phyllonorycter platani (Staudinger, 1870) (Marković \& Stojanović, 2012). Similar patterns are recorded for other species, like Dryocosmus kuriphilus (Yasumatsu, 1951) (Hymenoptera: Cynipidae) (Aebi et al., 2007; Matošević \& Melika, 2013), though the percentage parasitism of some invaders [Andricus quercuscalicis (Burgsdorf, 1783)] has increased over time (Schönrogge et al. 1995).
The factors that determine the number of parasitoid species parasitizing an invasive host have been studied by Cornell \& Hawkins (1993). They account for the development of parasitoid assemblages in terms of the effects of residence time, biological characteristics of the introduced species and the host spectrum of the native parasitoids. Similar temporal changes in the species composition of the parasitoids attacking $P$. issikii is to be expected. One important biological characteristic of the host in this respect is its phenology. Grabenweger (2004) found that while parasitoid adults are active in the spring, C. ohridella larvae at that time are not suitable for attack. Therefore, the effect of the parasitoid on this leafminer's first generation is very low. According to Marković \& Stojanović (2012), the percentage parasitism of the first generation of $P$. platani is also low. Similarly for $M$. robiniella the percentage parasitism of the first generation larvae is also a low (Csóka et al., 2009). In the case of $P$. issikii, larvae of both generations are very similar in terms of the timing of their development to the native Phyllonorycter species. However, studies indicate that native parasitoids are not able to regulate the populations of this recently arrived and established species.

Šefrová (2002) reports that the rate of development of the summer generation of $P$. issikii is strongly temperature dependent. Warmer temperatures result in faster development. Yefremova \& Mishchenko (2008) predict that the warming climate may allow a third generation to develop. Similar effects associated with climate change are recorded for other insects (Thomson et al., 2010). 


\section{The lime leaf miner Phyllonorycter issikii (Kumata, 1963)}

Phyllonorycter issikii (Kumata, 1963) (Lepidoptera: Gracillariidae) was described in 1963 from its native range, on Hokkaido, Japan. Its wingspan is ca. $6-8 \mathrm{~mm}$. Depending on the autumn mean temperature, it can have two to three generations per year in Central Europe (Perny, 2007) and Middle Volga basin (Yefremova \& Mishchenko, 2008). The first generation flies in May-June and the second in August-September, while its mines can be found from July until October (Szabóky \& Csóka, 2003; Mészáros \& Szabóky, 2005; Perny, 2007; pers. observ.). The tentiform blotch mines are regularly located on the underside of leaves and can generally be found towards the center of the leaf between veins, sometimes at the tip of a leaf (Mészáros \& Szabóky, 2005). A single larva develops within each mine. The caterpillar pupates within the mine and the adults overwinter there (Šefrová, 2002).

A summary of its spread is given by Ermolaev (2014). Outside its native range the moth was first found in Korea (Kumata et al., 1983). In Russia (Primorsky territory) it was first observed on Tilia amurensis (Ruprecht, 1869) and Tilia mandshurica (Ruprecht et Maximowicz, 1856) (Ermolaev, 1977), both of which are native plants. It was found developing well on Tilia cordata (Miller, 1768) in 1982 (Yefremova \& Mishchenko, 2008). According to Ermolaev (2014), in 1985 the moth reached Moscow. He describes two possible ways in which it might have been introduced into this region: cargo/transport (when the adults were hibernating) and the introduction with the host plant (as ornamental trees planted in parks).

By 2000-2002, the species had spread into the eastern part of Europe (Šefrová, 2002, 2003; Ermolaev \& Zorin, 2011, 2012; Ermolaev, 2014) possibly dispersed passively by wind (Šefrová, 2002). The speed of dispersal was estimated by Šefrová (2002) to be at least $110 \mathrm{~km} /$ year, and later by Rodeland (2007) as $200 \mathrm{~km} /$ year. The current limit to its southern distribution in Europe is Croatia (Matošević, 2007) and Bulgaria (Tomov, 2009), in the east and France (Reinhardt \& Rennwald, 2008) and England (Ermolaev, 2014) in the west. It was first reported in the north-eastern part of Hungary in 2003 (Szabóky \& Csóka, 2003).

The main damage it causes is considered to be primarily aesthetic, but according to Ermolaev \& Zorin (2011) high infestations can result in a decrease the nectar production of lime trees, causing serious economic loss to the honeybee keepers in Russia (Ermolaev \& Zorin, 2011) .

$P$. issikii may have a significant negative effect on the herbivore guild of Tilia. As it has become by far the most dominant herbivore species feeding on lime (Segerer, 2008; Jurc, 2012), in many places it may eventually outcompete the native leaf miner species Stigmella tiliae (Frey, 1856) and Bucculatrix thoracella (Thunberg, 1794).

\section{MATERIAL AND METHODS}

We summarized the data in the available literature and two online databases containing host-parasitoid associations: the Universal Chalcidoidea Database hosted by the British Natural Histo- ry Museum (Noyes, 2015) and the Global Taxonomic Database of Gracillariidae (Lepidoptera), hosted by the Belgian Biodiversity Platform (De Prins \& De Prins, 2014).

The dataset for Hungary resulted from our own 4-year rearing project (2011-2014). We collected only mature leaf mines of $P$. issikii from 19 localities throughout Hungary (Szőcs et al., 2014; unpubl.). The mines were cut from the leaves and after a short period of drying were put in air ventilated plastic tubes (in order to avoid the problems with mould) for individual rearing. All the literature data cited in the present work were obtained from similar rearing of individuals and therefore considered comparable.

The parasitoids that emerged were kept in ethanol until identified. We have retained samples for further genetic studies. The results obtained during the first three years are published (Szőcs et al., 2014).

The Shannon diversity index was calculated in order to compare the parasitoid complexes of different hosts, as Matošević \& Melika (2012) did in their paper. In order to estimate the significance of the differences in the diversity indexes, we used a twosample independent t-test.

\section{RESULTS AND DISCUSSION}

\section{The species composition of the complex}

The presence of the lime leaf miner on the Eurasian continent dates back to the 1970-s. After it spread rapidly local native natural enemies began to parasitize the lime leaf miner. Based on recently published papers 46 parasitoid species have been reared from this leaf miner. A list of the species is presented in Table 1. Forty two of these species belong to the superfamily Chalcidoidea and four to the Braconidae. Members of the Eulophidae are generally associated with leaf miners, especially those of the genus Phyllonorycter.

Of the parasitoid species reared in Japan, Dolichogenidea dilecta (Haliday, 1834), Chrysocharis ujiyei (Kamijo, 1977) (Hirao \& Murakami, 2008), Sympiesis laeviformis (Kamijo, 1977) and Pleurotroppopsis japonica (Kamijo, 1977) are not recorded in other countries parasitizing $P$. issikii. Common species shared with other countries are Elachertus fenestratus (Nees, 1834), Mischotetrastichus petiolatus (Erdős, 1961), Pediobius saulius (Walker, 1839) and Sympiesis sericeicornis (Nees, 1834) (Table 1). Achrysocharoides cilla (Walker, 1839) and Sympiesis angustipennis (Erdős, 1834) are only recorded emerging from this species in Hungary (Szőcs et al., 2014).

In Europe and Russia Tilia cordata is the primary host of P. issikii (Szabóky \& Csóka, 2003; Ermolaev, 2014; Kirichenko, 2014). In natural conditions, it grows as a component of mixed broadleaved forests (Pigott, 1975). Therefore, it might be easy for the native parasitoids to shift to parasitize the novel host.

Based on the data from 14 papers and our own rearing results, the parasitoid species that account for a significant part of lime leaf miner mortality are Chrysocharis laomedon (Delucci, 1954), Cirrospilus elegantissimus (Westwood, 1832), Hyssopus geniculatus (Hartig, 1838), Minotetrastichus frontalis (Nees, 1834), Pnigalio soemius (Walker, 1839), Sympiesis sericeicornis (Nees, 1834) and Sympiesis gordius (Walker, 1848) (Table 2). These species are generalist ectoparasitoids with a wide host range and 
TABLE 1. The species of parasitoids that have been recorded attacking $P$. issikii in the different areas it has recently colonized. UKR - Ukraine, RUS - Russia, JAP - Japan, BUL - Bulgaria, CRO - Croatia and HUN - Hungary.

\begin{tabular}{|c|c|c|c|c|c|c|c|c|c|c|c|c|c|c|}
\hline \multirow[b]{2}{*}{ Parasitoid species } & \multirow[b]{2}{*}{ 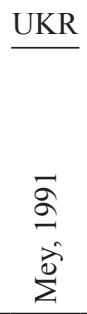 } & \multicolumn{4}{|c|}{ RUS } & \multicolumn{6}{|c|}{ JAP } & \multicolumn{3}{|c|}{ BUL CRO HUN } \\
\hline & & 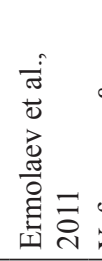 & 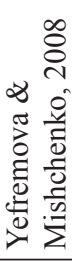 & 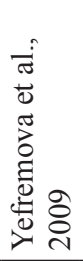 & 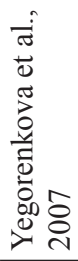 & 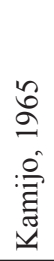 & 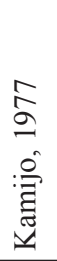 & 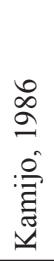 & $\begin{array}{l}\stackrel{2}{2} \\
\stackrel{\vec{D}}{\overrightarrow{\mid}}\end{array}$ & 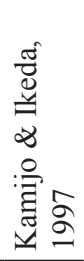 & 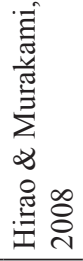 & 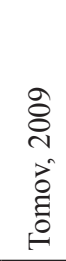 & 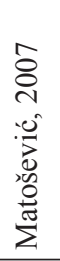 & 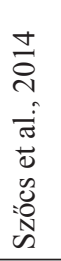 \\
\hline \multicolumn{15}{|l|}{ BRACONIDAE } \\
\hline Braconidae sp. & & & & & & & & & & & & & & - \\
\hline Pholetesor sp. & & & & & & & & & & & - & & & \\
\hline Dolichogenidea dilecta & & & & & & & & & & & - & & & \\
\hline Apanteles sp. & & • & • & & & & & & & & & & & • \\
\hline \multicolumn{15}{|l|}{ EULOPHIDAE } \\
\hline Achrysoscharoides cilla & & & & & & & & & & & & & & • \\
\hline Achrysocharoides sp. & & & & & & & & & & & • & & & \\
\hline Aprostocetus sp. & & & & • & & & & & & & & & & - \\
\hline Aprostocetus zoilus (Walker, 1839) & & & & & • & & & & & & & & & - \\
\hline Chrysocharis laomedon & - & • & • & • & & & & & & & & & & - \\
\hline Chrysocharis nephereus (Walker, 1839) & & • & & & & & & & & & & & & \\
\hline Chrysocharis phryne (Walker, 1839) & & - & & & & & & & & & & & & \\
\hline Chrysocharis pubicornis (Zetterstedt, 1838) & & - & & • & & & & & & & & & & \\
\hline Chrysocharis ujiyei (Kamijo, 1977) & & & & & & & & & & & • & & & \\
\hline Chrysocharis sp. & & & & & & & & & & & • & & & \\
\hline Cirrospilus sp. & & & & & & & & & & & • & & & \\
\hline Cirrospilus elegantissimus & • & & & • & & & & & & & & & & • \\
\hline Cirrospilus diallus & & • & • & • & & & & & & & & & & \\
\hline Cirrospilus lyncus & & • & • & • & & & & & & & & & & - \\
\hline Cirrospilus pictus & • & • & & & & & & & & & & & & \\
\hline Cirrospilus viticola & & & $\bullet$ & - & & & & & & & & & & - \\
\hline Cirrospilus vittatus & & • & & & & & & & & & & & & \\
\hline Dicladocerus westwoodi (Westwood, 1832) & & - & & & & & & & & & & & & \\
\hline Elachertus sp. & & & & & & & & & & & • & & & \\
\hline Elachertus fenestratus & & • & & & & & & & & & - & & & • \\
\hline Entedon sp. & & & • & & & & & & & & & & & \\
\hline Hyssopus nigritulus (Zetterstedt, 1838) & & - & & & & & & & & & & & & \\
\hline Hyssopus geniculatus & & - & • & - & & & & & & & & & & \\
\hline Minotetrastichus frontalis & - & • & • & • & • & & & & & & & • & & • \\
\hline Mischotetrastichus petiolatus & & • & & • & & & & & & $\bullet$ & & & & \\
\hline Neochrysocharis cuprifrons (Erdős, 1954) & & • & & & & & & & & & & & & \\
\hline Neochrysocharis formosus & & • & & & & & & & & & & & & • \\
\hline Oomyzus incertus (Ratzeburg, 1844) & & • & & • & & & & & & & & & & \\
\hline Pediobius cassidae (Erdős, 1958) & & & & • & & & & & & & & & & \\
\hline Pediobius metallicus (Nees, 1834) & & & & • & & & & & & & & & & \\
\hline Pediobius saulius & & & & & & & & - & & & & & & - \\
\hline Pleurotroppopsis japonica & & & & & & & • & & & & & & & \\
\hline Pnigalio agraules (Walker, 1839) & & & & & & & & & & & & & & • \\
\hline Pnigalio nemati (Westwood, 1838) & & • & & & & & & & & & & & & \\
\hline Pnigalio pectinicornis (Linnaeus, 1758) & & & & & & & & & & & & & & • \\
\hline Pnigalio soemius & & • & • & • & & & & & & & & & & • \\
\hline Sympiesis angustipennis & & & & & & & & & & & & & & • \\
\hline Sympiesis dolichogaster (Ashmead, 1888) & & $\bullet$ & & & & & & & & & & & & • \\
\hline Sympiesis gordius & • & • & • & • & & & & & & & & & & - \\
\hline Sympiesis laevifrons & & & & & & • & & & & & & & & \\
\hline Sympiesis sericeicornis & • & • & - & - & & • & & & & & & & • & - \\
\hline \multicolumn{15}{|l|}{ Pteromalidae } \\
\hline Pteromalidae sp. & & & $\bullet$ & & & & & & & & & & & \\
\hline
\end{tabular}


TABLE 2. The dominant species of parasitoids of $P$. issikii recorded in the different areas it has recently colonized. $\bullet-$ dominant species, $\bullet$ - secondary dominant species, $\cdots$ - tertiary dominant species. The dominance levels are those cited in the original papers.

\begin{tabular}{|c|c|c|c|c|c|c|c|}
\hline Parasitoid species & $\begin{array}{c}\text { Ukraine } \\
(\text { Mey, 1991) }\end{array}$ & $\begin{array}{c}\text { Russia } \\
\text { (Ermolaev } \\
\text { et al., 2011) }\end{array}$ & $\begin{array}{c}\text { Russia } \\
\text { (Yefremova \& } \\
\text { Mishchenko, 2008) }\end{array}$ & $\begin{array}{c}\text { Russia } \\
\text { (Yefremova } \\
\text { et al., 2009) }\end{array}$ & $\begin{array}{c}\text { Bulgaria } \\
\text { (Tomov, 2005) }\end{array}$ & $\begin{array}{c}\text { Croatia } \\
\text { (Matošević, } \\
\text { 2007) }\end{array}$ & $\begin{array}{l}\text { Hungary } \\
\text { (Szőcs } \\
\text { et al., 2014) }\end{array}$ \\
\hline Chrysocharis laomedon & & $\bullet \bullet$ & $\bullet$ & $\cdots$ & & & \\
\hline $\begin{array}{l}\text { Cirrospilus elegantissimus } \\
\text { Hyssopus geniculatus }\end{array}$ & $\cdots$ & & & & & & \\
\hline Minotetrastichus frontalis & & & •• & .• & • & & • \\
\hline Pnigalio soemius & & - & & & & & \\
\hline Sympiesis gordius & - & $\bullet$ & • & $\bullet$ & & & $\bullet$ \\
\hline Sympiesis sericeicornis & $\bullet$ & & & & & • & ... \\
\hline
\end{tabular}

are frequently recorded in large numbers from other invasive species, such as C. ohridella (Freise et al., 2002; Girardoz et al., 2006; Matošević \& Melika, 2012), P. platani (Mey, 1991; Balázs et al., 2002; Marković \& Stojanović, 2012; Matošević \& Melika, 2012), M. robiniella and P. robiniella (Csóka et al., 2009).

It is generally accepted that new resources (i.e. a new host) are primarily exploited by generalist species, which may be more flexible in their host searching behaviour and/ or adaptive potential and therefore more able to rapidly exploit a novel host. For example, S. gordius is known to be a generalist parasitoid with a broad host range. It is recorded as the dominant regulator of the lime leaf miner in Ukraine by Mey (1991), in the Middle Volga basin in Russia by Yefremova \& Mishchenko (2008) and Yefremova et al. (2009) and as a secondary parasitoid by Ermolaev et al. (2011). In Hungary, it was the third most dominant species. The larva of this species is a solitary (only one adult emerges from a mine) larval-pupal ectoparasitoid (Mishchenko \& Yefremova, 2012). The female lays an egg close to the host in a mine (Dowden, 1941). After the larva hatches, it kills the host and feeds on its haemolymph. The parasitoid pupa overwinters in the mine (Dowden, 1941). As a syn-ovigenic species, the adult matures eggs during its life time (Jervis et al., 2001, 2003; Ellers \& Jervis, 2004), therefore the protein resource obtained from the early stage leafminer larvae is important for the development of eggs (host feeding and stinging behaviour) (Jervis et al., 2008). This behaviour is very common among parasitoids (Askew \& Shaw, 1974; Urbaneja et al., 2002; Pinto et al., 2005; Bernardo et al., 2006). Similar behaviour is recorded for $P$. soemius, which is a dominant parasitoid with a significant effect on this host in Russia (Ermolaev et al., 2011). This parasitoid is also a primary (sometimes secondary) solitary ectoparasitoid with a broad host range. According to Bernardo et al. (2006) this species is predator-like in its behaviour: the adult often kills (by stinging) host larvae without feeding (host-feeding) or ovipositing in the mines and its larvae even migrate from one mine to another (Bernardo et al., 2006). Such behavior is hard to quantify in the field. These traits make $P$. soemius one of the most important population control agent in agricultural pest management (Bernardo et al., 2006). H. geniculatus is another dominant species of solitary ectoparasitoid (Ermolaev et al., 2011), which overwinters as a pupa (Brockerhoff \& Kenis, 1996).
This parasitoid was reared only from Russian samples (Ermolaev et al., 2011, 2013). C. lynchus, does not play an important role in the regulation of $P$. issikii, but is recorded emerging from this host in almost all the studies carried out in Europe and Russia. C. lyncus is a solitary ectoparasitoid, with the ability to behave as a secondary parasitoid. The eggs are laid on the host and the larvae overwinter (Urbaneja et al., 2002). In Hungary (Szöcs et al., 2014), and Bulgaria (Tomov, 2009) as well as in Russia (Yefremova et al., 2009), M. frontalis is also one of the main controlling agents of this leaf miner. This species is a gregarious (more than one egg is laid in a mine) ectoparasitoid, whose larvae can behave like a primary, secondary or tertiary parasitoid. The female lays eggs near the host (Yefremova \& Mishchenko, 2012) and it overwinters as a last instar larva (Lupi, 2005).

The parasitoids of the invasive $P$. issikii (just as in the case of other invasive species) include more idiobiont than koinobiont species. The more specialized koinobiont parasitoids need to adapt to the novel host's immune system (Pennacchio \& Strand, 2006). Therefore, the evolution of a koinobiont parasitoid complex takes longer. This may explain why only a few koinobiont parasitoids emerged from the Hungarian samples of $P$. issikii. In contrast, the parasitoid assemblages associated with native species of leaf miner tend to include more endoparasitoid species (Askew \& Shaw, 1979b; Sato, 1990; Szőcs et al., 2013; Yefremova \& Kravchenko, 2015). In Russia, where P. issikii has been present for longer, C. laomedon is an important koinobiont parasitoid (Yefremova \& Mishchenko, 2008; Ermolaev et al., 2011; Yefremova et al., 2013), being ranked the third most dominant at every location. As a koinobiont (host remains alive after it is parasitized) the adult lays an egg on the cuticle of a leaf miner larva. After hatching, the larvae leave the caterpillar and start to feed as an ectoparasitoid (Yefremova \& Mishchenko, 2012). This species is a primary parasitoid of a large number of leaf miners (De Prins \& De Prins, 2014; Noyes, 2015).

In all three places (Europe, Russia and Japan), the parasitoid complexes are diverse and generally composed of parasitoid species known from other Phyllonorycter species (Šefrová, 2003; Ermolaev et al., 2011; Matošević \& Melika, 2012; Szőcs et al., 2014). Comparisons made between the native parasitoid complexes of Phyllonorycter and $P$. issikii (same host family and different host plants) 
TABLE 3. Comparison of the diversity of endo- and ectoparasitoids recorded attacking native and non-native leaf miners in Hungary based on the Shannon diversity index and our own data. * Szőcs et al., 2014; unpubl.; ** Csóka et al., 2009; *** Szőcs et al., unpubl.

\begin{tabular}{|c|c|c|c|}
\hline \multirow{2}{*}{\multicolumn{2}{|c|}{ Leafminer hosts }} & \multicolumn{2}{|c|}{ Shannon diversity index } \\
\hline & & Endo & Ecto \\
\hline \multirow{2}{*}{ Invasive } & Phyllonorycter issikii* & 0.5 & 0.7 \\
\hline & Macrosaccus robiniella** & 0.4 & 0.6 \\
\hline \multirow{2}{*}{ Native } & Phyllonorycter comparella*** & 0.9 & 0.7 \\
\hline & Phyllonorycter roboris*** & 0.8 & 0.7 \\
\hline
\end{tabular}

show considerable overlap in the species of parasitoids (Yefremova \& Mishchenko, 2008; Matošević \& Melika, 2012; Szöcs et al., 2014; Yefremova \& Kravchenko, 2015). M. frontalis and A. cilla that are dominant in Hungary also parasitize non-gracillariid leaf miners, such as Parna apicalis (Brischke, 1888) (Hymenoptera: Tenthredinidae) and Stigmella tiliae (Frey, 1856) (Lepidoptera: Nepticulidae) living on the same food plant (T. cordata) (same food plant, different insect host family) (Szőcs et al., unpubl.).

The proportion of and diversity of ecto- and endoparasitoid species might be a good indicator of the degree of integration of a non-native species into the local fauna. There is no difference in the numbers of ectoparasitoid species parasitizing native and invasive species [based on our own records and those of Csóka et al. (2009)]. In the case of $P$. issikii, the number of ectoparasitoid species is higher than the number of endoparasitoid species (14 ectoparasitoid species to 7 endoparasitoid species) (Szöcs et al., 2014). Two other invasive species $(M$. robiniella and $P$. robiniella) are also parasitized by a lower number of endoparasitoid species than native leaf-miners of the genus Phyllonorycter. Shannon diversity indices (Table 3 ) indicate that the diversity of the ectoparasitoid complex of the invader differ greatly from that of the native species $(t=5.6569$, $\mathrm{p}=0.0299, \mathrm{p}<0.05$; for the two groups native/invasive).

The first native parasitoids to parasitize the novel host were most likely the species with a large host range, which encounter other species of leaf miners of the same genus, Phyllonorycter, on adjacent trees. Similar patterns of recruitment of host guild-associated parasitoids are recorded for invasive insect herbivores, for example the cynipid gall wasps on oak (Stone et al., 1995; Schönrogge et al., 1995, 1996) and chestnut (Aebi et al., 2007) in Europe.

\section{Percentage parasitism}

Generally the incidence of attacks by parasitoids and predators on invasive species of herbivorous insects is low, at least initially (Schönrogge et al., 1995, 2011; Grabenweger, 2004; Csóka et al., 2009; Marković \& Stojanović, 2012; Matošević \& Melika, 2012). The reasons are very simple. Initially, the local parasitoid fauna does not "recognize" the invasive species as a possible source of food. Alternatively, the invasive species may have a different life cycle such that native parasitoids are unable to detect the presence of this new food source. Examples include Cameraria ohridella (Grabenweger, 2004) and Parectopa robiniella (Csóka et al., 2009). In this case, the phenology of the native parasitoids needs to change if they are to track the novel hosts (Cornell \& Hawkins, 1993).

The life stages and phenology of Phyllonorycter issikii are rather similar to those of native Phyllonorycter species. Therefore, it should be easier for the native parasitoids to adapt to this novel host than in case of $C$. ohridella and $P$. robiniella. Csóka et al. (2009) report that the percentage parasitism of $P$. robiniella in Hungary (0.3-15.3\%) is much lower than that of $M$. robiniella (varied between $0.3-47.6 \%$ ) and that this difference is possibly due to differences in their life cycles and phenology and absence of a closely related species of Parectopa.

The percentage parasitism of $P$. issikii varies between $0.9 \%$ and $37.2 \%$ (Table 4 ) across the area it has recently colonized. These low levels of percentage parasitism indicate that this species is not yet well integrated into the local food-web. Clearly, the effect of native parasitoids is limited, as is the case for other invasive species.

Mortality of leaf miners caused by parasitoids acting as predators is very common, since not only the larvae, but also the adults, feed on host larvae (host feeding, maturation feeding). This behaviour is common among synovigenic species of parasitoids, because they need extra protein to produce more eggs (Flanders, 1950; Godfray, 1994; Jervis et al., 2001; Harvey et al., 2013). The adults attack the first 1-3 instar larvae of Phyllonorycter. In fact, more Phyllonorycter are killed as a result of host-feeding by adult parasitoids than by parasitism (Askew \& Shaw, 1979a, b). After host-feeding, female wasps' most likely search for oviposition sites close to the feeding location because on heavily infested leaves (mainly in the second generation), mines in different developmental stages can be found. The mortality caused by adult parasitoids as a result of their "maturation" feeding is usually not included in

TABLE 4. The percentage parasitism of $P$. issikii recorded in the different areas it has recently colonized.

\begin{tabular}{lccc}
\hline Country / Location & Source & Rearing time & Parasitation \% \\
\hline Ukraine / Kiev & Mey, 1991 & 1988 & $2.9-22.2$ \\
Russia / Izhevsk & Ermolaev et al., 2011 & $2001-2005$ & $0.9-12.5$ \\
Russia / Volga basin & Yefremova \& Mischcenko, 2008 & 2006 & $7-37$ \\
Romania & Stolnicu \& Ureche, 2007 & 2006 & 22.2 \\
Bulgaria & Tomov, 2009 & Unknown & $13.7-16.1$ \\
Hungary & Szöcs et al., 2014; unpubl. & $2011-2014$ & $9.6-37.2$ \\
\hline
\end{tabular}


estimates of the percentage of hosts killed by these parasitoids. Therefore, the regulating potential of these ectoparasitoids is likely to be considerably greater than previously considered. This is likely to be the most important group of parasitoids of the lime leaf miner, particularly in the early stages of colonization.

ACKNOWLEDGEMENTS. This project was supported by an OTKA (Hungarian Scientific Research Fund) 84096 research grant (Parasitoid assemblages of leaf miners in mixed broadleaved forests). We are grateful to G. Stone (The University of Edinburgh) for his advice and checking the English of the manuscript.

\section{REFERENCES}

Aebi A., Melika G., Quacchia A., Alma A. \& Stone G.N. 2007: Native and introduced parasitoids attacking the invasive chestnut gall wasp Dryocosmus kuriphilus. - OEPP/EPPO Bull. 37: $166-171$

AsKew R.R. \& SHAw M.R. 1974: An account of the Chalcidoidea (Hymenoptera) parasitising leaf-mining insects of deciduous trees in Britain. - Biol. J. Linn. Soc. 6: 289-335.

AsKew R.R. \& SHAw M.R. 1979a: Mortality factors affecting the leaf-mining stages of Phyllonorycter (Lepidoptera: Gracillariidae) on oak and birch (1. Analysis of the mortality factors). —Zool. J. Linn. Soc. 67: 31-49.

Askew R.R. \& SHaw M.R. 1979b: Mortality factors affecting the leaf-mining stages of Phyllonorycter (Lepidoptera: Gracillariidae) on oak and birch (2. Biology of the parasite species). Zool. J. Linn. Soc. 67: 51-64.

Balázs K., Thuróczy C. \& RipKa G. 2002: Parasitoids of the horse chestnut leafminer Cameraria ohridella Deschka et Dimic, 1986 (Lepidoptera: Gracillariidae) in Hungary. In Melika G. \& Thuróczy C. (eds): Parasitic Wasps: Evolution, Systematics, Biodiversity and Biological Control. Agroinform, Budapest, pp. 405-412.

Bernardo U., Pedata P.A. \& Viggiani G. 2006: Life history of Pnigalio soemius (Walker) (Hymenoptera: Eulophidae) and its impact on a leafminer host through parasitization, destructive host-feeding and host-stinging behavior. - Biol. Contr. 37: 98-107.

Brockerhoff E.G. \& KenIS M. 1996: Parasitoids associated with Cydia strobilella (L.) (Lepidoptera: Tortricidae) in Europe, and considerations for their use for biological control in North America. - Biol. Contr. 6: 202-214.

Cornell H.W. \& Hawkins B.A. 1993: Accumulation of native parasitoid species on introduced herbivores: A comparison of hosts as natives and hosts as invaders. - Am. Nat. 141: 847865

Csóka G., Pénzes Z., Hirka A., Mikó I., Matošević D. \& Melika G. 2009: Parasitoid assemblages of two invading black locust leaf miners, Phyllonorycter robiniella and Parectopa robiniella in Hungary. - Period. Biol. 111: 405-411.

De Prins J. \& De Prins W. 2014: Global Taxonomic Database of Gracillariidae (Lepidoptera). http://www.gracillariidae.net Accessed 15 February 2015.

DowdEn P.B. 1941: Parasites of the birch beaf-mining sawfly (Phyllotoma nemorata). — USDA Tech. Bull. 757: 25-30.

ElLers J. \& JeRvis M.A. 2004: Why are so few parasitoid wasp species pro-ovigenic? - Evol. Ecol. Res. 6: 993-1002.

Ermolaev I.V. 1977: Eco-faunistic review of leafminers (Lepidoptera, Gracillariidae) of the Southern Primorskii Territory. — Trudy Zool. Inst. Ross. Akad. Nauk 70: 98-116.
Ermolaev I.V. 2014: Biological invasion of the lime leafminer Phyllonorycter issikii Kumata (Lepidoptera, Gracillariidae) in Europe. - Contemp. Probl. Ecol. 7: 324-333.

ERmolaev I.V. \& Zorin D.A. 2011: Ecological consequences of invasion of Phyllonorycter issikii (Lepidoptera, Gracillariidae) in lime forests in Udmurtia. - Entomol. Rev. 91: 592-598.

ERmolaev I.V. \& Zorin D.A. 2012: Distribution of the lime leafminer Phyllonorycter issikii (Lepidoptera, Gracillariidae) in natural stands. - Entomol. Rev. 91: 1088-1091.

Ermolaev I.V., Yefremova Z.A. \& Izhboldina N.V. 2011: Parasitoids as a mortality factor for the lime leafminer (Phyllonorycter issikii, Lepidoptera, Gracillariidae). — Entomol. Rev. 91: $326-334$.

FLANDERS S.E. 1950: Regulation of ovulation and egg disposal in the parasitic Hymenoptera. - Can. Entomol. 82: 134-140.

Freise J.F., Heitland W. \& Tosevski I. 2002: Parasitism of the horse chestnut leaf miner, Cameraria ohridella Deschka and Dimic (Lep., Gracillariidae), in Serbia and Macedonia. - $J$. Pest Sci. 75: 152-157.

Fry J.M. 1989: Natural Enemy Databank, 1987. A Catalogue of Natural Enemies of Arthropods Derived from Records in the CIBC Natural Enemy Databank, 8: 185. CAB International, Wallingford.

Girardoz S., Kenis M. \& Quicke D.L.J. 2006: Recruitment of native parasitoids by an exotic leaf miner, Cameraria ohridella: host-parasitoid synchronization and influence of the environment. - Agric. Forest Entomol. 8: 49-56.

Godfray H.C.J. 1994: Parasitoids: Behavioral and Evolutionary Ecology. Princeton University Press, Princeton, N.J., 488 pp.

Grabenweger G. 2004: Poor control of the horse chestnut leafminer, Cameraria ohridella (Lepidoptera: Gracillariidae), by native European parasitoids: a synchronisation problem. Eur. J. Entomol. 101: 189-192.

Grabenweger G., Stolz M., Augustin S., Guichard S., Avtzis N., Bacher S., Kehrli P., Freise J., Heitland W., Girardoz S., Kenis M., Lethmayer C., Tomov R. \& Volter L. 2005: Reasons for and effects of changes in the parasitoid complex of the horse chestnut leafminer, Cameraria ohridella (Lepidoptera: Gracillariidae). In: Plant Protection and Plant Health in Europe: Introduction and Spread of Invasive Species. Symposium Proceedings of the British Crop Protection Council No. 81, Berlin, 9.-11. June, 2005. BCPC, Alton (UK), pp. 179-184.

Harvey J.A., Poelman E.H. \& TanaKa T. 2013: Intrinsic interand intraspecific competition in parasitoid wasps. - Annu. Rev. Entomol. 58: 333-351.

Hawkins B.A. 2005: Pattern and Process in Host-Parasitoid Interactions. Cambridge University Press, Cambridge, 412 pp.

Hirao T. \& Murakami M. 2008: Quantitative food webs of lepidopteran leafminers and their parasitoids in a Japanese deciduous forest. - Ecol. Res. 231: 159-168.

Jervis M.A., Heimpel G.E., Ferns P.N., Harvey J.A. \& Kidd N.A.C. 2001: Life-history strategies in parasitoid wasps: a comparative analysis of "ovigeny." - J. Anim. Ecol. 70: 442458.

Jervis M.A., Ferns P.N. \& Heimpel G.E. 2003: Body size and the timing of egg production in parasitoid wasps: a comparative analysis body size and the timing of egg production in parasitoid wasps: a comparative analysis. - Funct. Ecol. 17: 375-383.

Jervis M.A., Ellers J. \& Harvey J.A. 2008: Resource acquisition, allocation, and utilization in parasitoid reproductive strategies. - Annu. Rev. Entomol. 53: 361-385.

JuRC M. 2012: The lime leafminer (Phyllonorycter issikii) in Slovenia. - Sumarski List 136: 119-127. 
Kamiso K. 1965: Descriptions of five new species of Eulophinae from Japan and other notes (Hymenoptera: Chalcidoidea). Insecta Matsum. 28: 69-78.

Kamiso K. 1977: Five new species of Cotterellia (Hymenoptera, Eulophidae) from Japan. — Kontyû 45: 253-261.

Kaмiso K. 1986: Description of a new species of Desmatocharis Graham (Hymenoptera, Eulophidae), with notes on other species. - Kontyûu 54: 243-245.

Kamijo K. \& Ikeda E. 1997: A revision of Citrostichus and Mischotetrastichus (Hymenoptera: Eulophidae), with descriptions of a new genus and new species. - Japan. J. Entomol. 65: $562-582$.

KIRICHENKo N.I. 2014: The lime leafminer Phyllonorycter issikii in Western Siberia: Some ecological characteristics of the population of the recent invader. - Contemp. Probl. Ecol. 7: 114-121.

Kumata T. 1963: Taxomonic studies on the Lithocolleinae of Japan (Lepidoptera: Gracillariidae) Part 1. — Insecta Matsum. 25: 53-90.

Kumata T., Kuroko H. \& Park K.T. 1983: Some Korean species of the subfamily Lithocolletinae (Gracillariidae, Lepidoptera). - Kor. J. Plant Prot. 22: 213-227.

LuPI D. 2005: A 3 year field survey of the natural enemies of the horse-chestnut leaf miner Cameraria ohridella in Lombardy, Italy. - BioControl 50: 113-126.

Marković Č. \& Stojanović A. 2012: Parasitoids of Phyllonorycter platani (Staudinger) (Lepidoptera, Gracillariidae) in Serbia. - J. Plant Stud. 1: 79-84.

MATOŠEVIĆ D. 2007: First record of Phyllnorycter issikii and distribution of invasive leafminer species from the family of Gracillariidae in Croatia. - Sumar. Inst. Jastr. 42: 127-142.

MatošEvić D. \& MeliKa G. 2012: Diversity of parasitoid assemblages of native and alien leaf miners in Croatia. - Sumar. List 442: 367-376.

MatošEvić D. \& MeliKa G. 2013: Recruitment of native parasitoids to a new invasive host: first results of Dryocosmus kuriphilus parasitoid assemblage in Croatia. - Bull. Insectol. 66: $231-238$

MészÁros Z. \& SzABóKy C. 2005: The practical album of the Hungarian micromoths. - Növényvédelem (Suppl.): 178 pp. [in Hungarian].

MEY W. 1991: On the significance of native parasitoid complexes in the current range extension by four Phyllonorycter species into Europe (Insecta, Lepidoptera, Hymenoptera). - Mitt. Zool. Mus. Berl. 67: 177-194.

NoYes J.S. 2015: Universal Chalcidoidea Database. http://www. nhm.ac.uk/research-curation/research/projects/chalcidoids/database/ Accessed 1 January 2014

Pennacchio F. \& Strand M.R. 2006: Evolution of developmental strategies in parasitic Hymenoptera. - Annu. Rev. Entomol. 51: 233-258.

Perny B. 2007: Lindenminiermotte Phyllonorycter issikii: Vorkommen in Österreich nach mehreren Verdachtsfällen nun bestätigt. - Forstsch. Aktuell 38: 9-11.

PigotT C.D. 1975: Natural regeneration of Tilia cordata in relation to forest-structure in the forest of Bialowieza, Poland. Phil. Transact. R. Soc. Lond. (B) 270: 151-179.

Pinto M.L., Salerno G. \& Wajnberg E. 2005: Biology and behaviour of Cirrospilus diallus and Cirrospilus pictus, parasitoids of Phyllocnistis citrella. - BioControl 50: 921-935.

ReInhardt R. \& Rennwald E. 2008: Phyllonorycter issikii (Kumata, 1963) jetzt auch in Sachsen-Anhalt: mit einem Überblick über den gegenwärtigen Stand der Arealerweiterung in Deutschland (Lepidoptera, Gracillariidae). — Entomol. Nachr. Ber. 51: 233-233.
Rodeland J. 2007: Erstnachweis von Phyllonorycter issikii (Kumata, 1963) (Lepidoptera: Gracillariidae) für Rheinland-Pfalz. — Mainz. Naturwiss. 45: 279-281.

Sato H. 1990: Parasitoid complexes of Lepidopteran leaf miners on oaks (Quercus dentata and Quercus mongolica) in Hokkaido, Japan. - Ecol. Res. 5: 1-8.

Schönrogge K., Stone G.N. \& Crawley M.J. 1995: Spatial and temporal variation in guild structure: parasitoids and inquilines of Andricus quercuscalicis (Hymenoptera: Cynipidae) in its native and alien ranges. - Oikos 72: 51-60.

Schönrogge K., Stone G.N. \& Crawley M.J. 1996: Alien herbivores and native parasitoids: rapid development of guild structure in an invading gall wasp, Andricus quercuscalicis (Hymenoptera: Cynipidae). - Ecol. Entomol. 21: 71-80.

Schönrogge K., Begg T., Williams R., Melika G., Randle Z. \& Stone G.N. 2011: Range expansion and enemy recruitment by eight alien gallwasp species in Britain. - Insect Conserv. Div. 5: $298-311$.

ŠEfrová H. 2002: Phyllonorycter issikii (Kumata, 1963) - bionomics ecological impact and spread in Europe (Lepidoptera, Gracillariidae). - Acta Univ. Agric. Silvic. Mendel. Brun. 50: 99-104.

ŠEFrovÁ H. 2003: Invasions of Lithocolletinae species in Europe - causes, kinds, limits and ecological impact (Lepidoptera, Gracillariidae). - Ekologia (Bratislava) 22: 132-142.

Segerer A. 2008: Der Lindenminierfalter Phyllonorycter issikii (Kumata, 1963) - ein wenig bekanntes Neozoon in Bayern (Lepidoptera: Gracillariidae). — Nachrichtenbl. Bayer. Entomol. 57: 74-78

Stolnicu A.-M. \& UReche C. 2007: Data regarding the presence of the Phyllonorycter issikii (Kumata) (Lepidoptera: Gracillariidae) in romanian fauna. - Anal. Ştiinţ. Univ. Al. I. Cuza 53: 103-108.

Stone G.N., Schönrogge K., Crawley M.J. \& Fraser S. 1995: Geographic variation in the parasitoid community associated with an invading gallwasp, Andricus quercuscalicis (Hymenoptera: Cynipidae). - Oecologia 104: 207-217.

SzABóKY C. \& CsóKA G. 2003: The occurrence of the lime leafminer (Phyllonorycter issikii Kumata, 1963; Lep. Gracillariidae) in Hungary. - Növényvédelem 39: 23-24 [in Hungarian].

SzŐCs L., Melika G. \& CsóKa G. 2013: Data on the parasitoid complexes of leaf mining insects on oaks. - Erdészettudományi Közlemények 3: 251-259 [in Hungarian].

Szöcs L., Melika G., Thuróczy C. \& CsóKa G. 2014: Data on the parasitoid complexes of the invasive lime leafminer moth (Phyllonorycter issikii Kumata, 1963). — Növényvédelem 50: 445-451 [in Hungarian].

Thomson L.J., Macfadyen S. \& Hoffmann A.A. 2010: Predicting the effects of climate change on natural enemies of agricultural pests. - Biol. Contr. 52: 296-306.

Tomov R. 2009: A review of mortality factors of three invasive leafminer moths (Lepidoptera) in Bulgaria. In Stojnić B. (ed.): VI. Congress of Plant Protection with Symposium about Biological Control of Invasive Species, Zlatibor, 23.-27. November 2009. Book of Abstracts and Papers II. Plant Protection Society of Serbia, Beograd, pp. 83-85.

Urbaneja A., Hinarejos R., Llácer E., Garrido A. \& Jacas J.A. 2002: Effect of temperature on life history of Cirrospilus vittatus (Hymenoptera: Eulophidae), an ectoparasitoid of Phyllocnistis citrella (Lepidoptera: Gracillariidae). - J. Econ. Entomol. 95: 250-255.

Volter L. \& Kenis M. 2006: Parasitoid complex and parasitism rates of the horse chestnut leafminer, Cameraria ohridella 
(Lepidoptera: Gracillariidae) in the Czech Republic, Slovakia and Slovenia. - Eur. J. Entomol. 103: 365-370.

YeFremova Z.A. \& KRAVChENKO V.D. 2015: Interactions among host plants, Lepidoptera leaf miners and their parasitoids in the forest-steppe zone of Russia (Insecta: Lepidoptera, Hymenoptera). - SHILAP Revta Lepidopterol. 43: 271-280.

Yefremova Z.A. \& MishchenKo A.V. 2008: The parasitoid complex (Hymenoptera, Eulophidae) of the leafminer Phyllonorycter issikii (Kumata) (Lepidoptera, Gracillariidae) from the Middle Volga Basin. - Entomol. Rev. 88: 178-185.

Yefremova Z.A. \& Mishchenko A.V. 2012: The preimaginal stages of Minotetrastichus frontalis (Nees) and Chrysocharis laomedon (Walker) (Hymenoptera: Eulophidae), parasitoids associated with Phyllonorycter issikii (Kumata) (Lepidoptera, Gracillariidae). - J. Nat. Hist. 46: 1283-1305.
Yefremova Z.A., Krayushkina A.V. \& MishchenKo A.V. 2009: Parasitoid complexes (Hymenoptera, Eulophidae) of leafminers of the genus Phyllonorycter (Lepidoptera, Gracillariidae) in the Middle Volga Basin. — Entomol. Rev. 89: 903-911.

Yefremova Z.A., Yegorenkova E.N. \& Mishchenko A.V. 2013: Eulophid wasps (Hymenoptera, Eulophidae), parasitoids of leaf-mining moths (Lepidoptera: Gracillariidae, Nepticulidae, Tischeriidae) on the English oak in the Middle Volga area. Entomol. Rev. 93: 591-597.

Yegorenkova E.N., Yefremova Z.A. \& Kostjukov V.V. 2007: Contributions to the knowledge of Tetrastichine wasps (Hymenoptera, Eulophidae, Tetrastichinae) of the Middle Volga region. - Entomol. Rev. 87: 1180-1192.

Received April 27, 2015; revised and accepted July 28, 2015 Prepublished online October 8, 2015 